\title{
PENGARUH AKUNTABILITAS ALOKASI DANA DESA, KEBIJAKAN DESA DAN KELEMBAGAAN DESA ATAS PENGELOLAAN KEUANGAN DESA WISATA (Studi Empiris pada Desa-Desa di Kecamatan Banjar)
}

\author{
Ketut Teddy Wisastrawan', Ni Luh Gede Erni Sulindawati², \\ I Nyoman Putra Yasa ${ }^{3}$
}

\author{
Jurusan Ekonomi dan Akuntansi, Fakultas Ekonomi. Universitas Pendidikan Ganesha \\ Singaraja, Indonesia
}

e-mail: teddywisastrawan997@gmail.com, esulind@gmail.com, putrayasainym@undiksha.ac.id

\begin{abstract}
Abstrak
Penelitian ini bertujuan untuk mengetahui pengaruh akuntabilitas alokasi dana desa, kebijakan desa dan kelembagaan desa terhadap pengelolaan keuangan desa wisata. Penelitian ini menggunakan metode penelitian kausal komparatif yang merupakan penelitian dengan karakteristik masalah berupa hubungan sebab-akibat antara dua variabel atau lebih. Penelitian ini dilakukan pada desa wisata di Kecamatan Banjar. Populasi dalam penelitian ini adalah seluruh Kepala Desa serta Perangkat Desa di Kecamatan Banjar Kabupaten Buleleng. Metode pengambilan sampel yang digunakan dalam penelitian ini adalah metode purposive sampling, sehingga diperoleh sampel sejumlah 60 responden. Data penelitian ini dikumpulkan dengan menggunakan kuesioner yang kemudian diolah dengan uji analisis regresi linear berganda dengan bantuan SPSS versi 22. Hasil penelitian menyatakan bahwa akuntabilitas alokasi dana desa, kebijakan desa, dan kelembagaan desa secara individual maupun secara bersama-sama berpengaruh signifikan terhadap pengelolaan keuangan desa wisata di Kecamatan Banjar.
\end{abstract}

Kata kunci: Pengelolaan keuangan, akuntabilitas, kebijakan, kelembagaan desa

\begin{abstract}
This research aimed at determining the accountability effect of village fund allocation, village policy and village institution on the tourism villages' financial management. This research employed a comparative causal research method which is a study with the characteristics of a problem in the form of a causal relationship between two or more variables. This research was conducted on tourism villages in Banjar Sub-District. The research population was all the Village Heads and Village officials in Banjar Sub-District, Buleleng Regency. The sampling method used in this research was purposive sampling method, so that a sample of 60 respondents was obtained. The research data were collected through a questionnaire which was then processed through multiple linear regression analysis test with the assistance of SPSS version 22. The results of the research showed that the village fund allocation accountability, village policy, and village institution individually and simultaneously had a significant effect on the tourism villages' financial management in Banjar Sub-District.
\end{abstract}

Keywords: Financial management, accountability, policy, village institutions

\section{Pendahuluan}

Desa adalah komunitas kecil yang terikat pada lokalitas tertentu baik sebagai tempat tinggal dan juga tempat pemenuhan kebutuhan hidup masyarakat desa yang bergantung kepada pertanian (Rahardjo, 2007) dalam (Justita 2016). Masyarakat itu sendiri mempunyai dua sifat yaitu ada yang bersifat terbuka yang bisa menerima perubahan-perubahan yang terjadi dilingkungan masyarakat dan menggabungkan berbagai jenis kebudayaan yang sudah ada, dan sebaliknya masyarakat yang mempunyai sifat tertutup cenderung sulit untuk 
menerima perubahan-perubahan karena mereka tidak terbiasa melakukan sesuatu yang mereka tidak pahami dan tidak biasa mereka jalankan, biasanya juga terjadi pada masyarakat yang masih tradisional dan tinggal di daerah pedesaan.

Untuk menjalankan operasional desa diperlukan dana desa yaitu dana yang bersumber dari Anggaran Pendapatan dan Belanja Negara yang diperuntukkan bagi Desa dan Desa Adat yang ditransfer melalui Anggaran Pendapatan dan Belanja Daerah kabupaten/kota dan digunakan untuk membiayai penyelenggaran pemerintahan, pembangunan, serta pemberdayaan masyarakat, dan kemasyarakatan. Fokus penting dari penyaluran dana ini lebih terkait pada implementasi pengalokasian Dana Desa agar bisa sesempurna gagasan para inisiatornya (Subroto, 2009).

Prinsip otonomi daerah menggunakan prinsip otonomi yang seluas-luasnya berarti daerah diberikan kewenangan mengurus dan mengatur semua urusan pemerintahan di luar yang menjadi urusan pemerintah yang ditetapkan dalam Undang-Undang. Maka dari itu, isi dan jenis otonomi bagi setiap daerah berbeda-beda. Namun, prinsip dalam otonomi daerah tetap sama, yaitu penyelenggaraan otonomi daerah harus selalu beorientasi pada peningkatan kesejahteraan masyarakat dengan selalu memperhatikan kepentingan dan aspirasi yang tumbuh di masyarakat (Ompi, 2012).

Berdasarkan Peraturan Pemerintah Nomor 72 Tahun 2005 tentang Desa pasal 68 ayat 1 poin $\mathrm{c}$, menyebutkan bahwa bagian dari dana perimbangan pusat dan daerah yang diterima oleh kabupaten/kota untuk desa, paling sedikit 10\% secara proposional pembagiannya untuk setiap desa, dana ini dalam bentuk Alokasi Dana Desa (ADD). Dana ini merupakan dana yang dialokasikan oleh Pemerintah Kabupaten untuk desa, yang bersumber dari bagian dana perimbangan keuangan pusat dan daerah yang diterima oleh Kabupaten. Alokasi Dana Desa merupakan dana yang cukup signifikan bagi Desa untuk menunjang program-program Desa (Azwardi, 2014).

Kecamatan Banjar adalah sebuah kecamatan di Kabupaten Buleleng, Propinsi Bali, Indonesia. Kecamatan ini berjarak sekitar $17 \mathrm{Km}$ dari Singaraja, ibukota Kabupaten Buleleng ke arah barat. Pusat pemerintahannya berada di Desa Banjar. Kecamatan Banjar terdiri dari 17 Desa, tetapi Desa yang termasuk Desa wisata di Kecamatan Banjar hanya ada 10 Desa yaitu Desa Banjar, Desa Banjar Tegeha, Desa Munduk, Desa Dencarik, Desa Sidetapa, Desa Pedawa, Desa Tigawasa, Desa Cempaga, Desa Banyuseri dan Desa Temukus. Dalam penelitian ini desa yang diambil adalah sebanyak 6 desa, karena yang termasuk desa wisata yang berpenghasilan yaitu Desa Temukus, Desa Dencarik, Desa Banjar Tegeha, Desa Banjar, Desa Pedawa dan Desa Munduk. Dari ke 6 desa ini cukup menarik untuk diteliti karena desa tersebut tidak hanya mendapat dana dari pemerintah, melainkan mendapat dana dari para wisatawan yang berkunjung untuk melihat dan membeli prasarana yang dijual diwisata tersebut, keuntungan yang didapat cukup besar untuk mengembangkan wisata tersebut agar mendapat keuntungan yang lebih banyak lagi.

Menurut Pasal 1 Peraturan Menteri Dalam Negeri Nomor 113 Tahun 2014 tentang Pengelolaan Keuangan Desa menyebutkan bahwa Alokasi Dana Desa adalah dana yang diberikan kepada desa yang berasal dari dana perimbangan keuangan pemerintah pusat dan daerah yang diterima oleh kabupaten/kota setelah dikurangi Dana Alokasi Khusus. Kemudian kebijakan pemerintah desa merupakan salah satu produk hukum karena setiap pemerintah desa secara hukumpun memiliki wewenang tersebut.meskipun berskala kecil dan lokal yang mencangkup wilayah administrasi desa itu sendiri.

Secara undang-undang, kebijakan formal di level desa tertuah dalam bentuk peraturan desa. Sesuai dengan amanat Undang-Undang Nomor 6 Tahun 2014 tentang Desa, Pemerintah mengalokasikan Dana Desa, melalui mekanisme transfer kepada Kabupaten/Kota. Berdasarkan alokasi Dana tersebut, maka tiap Kabupaten/Kota mengalokasikannya ke pada setiap desa berdasarkan jumlah desa dengan memperhatikan jumlah penduduk $30 \%$, luas wilayah $20 \%$, dan angka kemiskinan $50 \%$. Hasil perhitungan tersebut disesuaikan juga dengan tingkat kesulitan geografis masingmasing desa. Alokasi anggaran sebagaimana dimaksud di atas, bersumber dari Belanja Pusat dengan mengefektifkan program yang berbasis Desa secara merata dan berkeadilan. 
Otonomi daerah sangat mendorong Pemerintah Desa untuk lebih memberdayakan masyarakat dan mengoptimalkan sumberdaya yang ada baik itu sumberdaya dari desa sendiri maupun dari luar. Adanya Alokasi Dana desa (ADD) tersebut, desa memiliki kewenangan untuk mengatur dan mengurus rumah tangganya sesuai dengan kewenangan yang diberikan, yang menyangkut peranan pemerintah desa sebagai penyelenggara pelayanan publik di desa dan sebagai tujuan dalam proses perencanaan dan pelaksanaan pembangunan daerah yang melibatkan masyarakat di tingkat desa.. Penelitian mengenai alokasi dana desa pernah dilakukan oleh Justita (2016) yang menyatakan bahwa akuntabilitas alokasi dana desa berpengaruh terhadap kesejahteraan masyarakat di desa Gubugklakah Kecamatan Poncokusumo Kabupaten Malang. Hasil penelitian Lina (2017) juga menyatakan bahwa untuk pemerintah daerah maupun pemerintah desa agar selalu mewujudkan akuntabilitas pengelolaan keuangan desa di Kabupaten Jombang. Karenanya peneliti berasumsi bahwa :

$\mathrm{H} 1$ : Akuntabilitas alokasi dana desa berpengaruh positif dan signifikan terhadap pengelolaan keuangan desa wisata

Kebijakan pemerintah desa merupakan salah satu produk hukum karena setiap pemerintah desa secara hukumpun memiliki wewenang tersebut.meskipun berskala kecil dan lokal yang mencangkup wilayah administrasi desa itu sendiri. Secara undang-undang, kebijakan formal di level desa tertuah dalam bentuk peraturan desa. Meskipun demikian desa memiliki hak dan wewenang berpartisipasi dalam menentukan arah pembangunan nasional secara umum serta pembangunan desa sendiri secara khusus. Penelitian mengenai kebijakan desa pernah dilakukan oleh Justita (2016) yang menyatakan bahwa kebijakan desa berpengaruh terhadap kesejahteraan masyarakat di desa Gubugklakah Kecamatan Poncokusumo Kabupaten Malang. Berdasarkan uraian di atas, maka hipotesis kedua yang diajukan adalah sebagai berikut:

H2: Kebijakan desa berpengaruh positif dan signifikan terhadap pengelolaan keuangan desa wisata.

Lembaga atau institusi adalah wadah untuk mengemban tugas dan fungsi tertentu dalam rangka mencapai tujuan tertentu. Oleh karena itu, keberadaan lembaga desa merupakan wadah untuk mengemban tugas dan fungsi Pemerintahan Desa. Istilah lembaga identik dengan organisasi. Dalam suatu organisasi senantiasa terdapat struktur organisasi yang jelas. Di dalam kehidupan organisasi senantiasa terjadi hubungan kerja antar unit- unit kerja dalam organisasi itu. Penelitian mengenai kelembagaan desa pernah dilakukan oleh Justita (2016) yang menyatakan bahwa kelembagaan desa berpengaruh terhadap kesejahteraan masyarakat di desa Gubugklakah Kecamatan Poncokusumo Kabupaten Malang. Berdasarkan uraian di atas, maka hipotesis ketiga yang diajukan adalah sebagai berikut:

$\mathrm{H}_{3}$ : Kelembagaan desa berpengaruh positif dan signifikan terhadap pengelolaan keuangan desa wisata

Pengelolaan keuangan desa adalah keseluruhan kegiatan yang meliputi perencanaan, pelaksanaan, penatausahaan, pelaporan, dan pertanggungjawaban keuangan desa. Penyelenggaraan kewenangan lokal berskala Desa selain didanai oleh APB Desa, juga dapat didanai oleh anggaran pendapatan dan belanja negara dan anggaran pendapatan dan belanja daerah. Penyelenggaraan kewenangan Desa yang ditugaskan oleh Pemerintah didanai oleh anggaran pendapatan dan belanja negara. Dengan adanya Alokasi Dana desa (ADD), desa memiliki kewenangan untuk mengatur dan mengurus rumah tangganya sesuai dengan kewenangan yang diberikan, yang menyangkut peranan pemerintah desa sebagai penyelenggara pelayanan publik di desa dan sebagai tujuan dalam proses perencanaan dan pelaksanaan pembangunan daerah yang melibatkan masyarakat di tingkat desa. Berdasarkan uraian di atas, maka hipotesis keempat yang diajukan adalah sebagai berikut:

$\mathrm{H}_{4}$ : Akuntabilitas alokasi dana desa, kebijakan desa, dan kelembagaan desa secara bersama-sama berpengaruh terhadap pengelolaan keuangan desa wisata.

Berdasarkan uraian di atas, adapun tujuan penelitian ini, yaitu untuk mengetahui (1) pengaruh akuntabilitas alokasi dana desa terhadap pengelolaan keuangan desa wisata di 
Kecamatan Banjar, (2) pengaruh kebijakan desa terhadap pengelolaan keuangan desa wisata di Kecamatan Banjar, (3) pengaruh kelembagaan desa terhadap pengelolaan keuangan desa wisata di Kecamatan Banjar, dan (4) pengaruh akuntabilitas alokasi dana desa, kebijakan desa, dan kelembagaan desa terhadap pengelolaan keuangan desa wisata di Kecamatan Banjar.

\section{Metode}

Penelitian ini termasuk dalam penelitian kausal komparatif yang merupakan penelitian dengan karakteristik masalah berupa hubungan sebab-akibat antara dua variabel atau lebih, dan peneliti dapat mengidentifikasi fakta atau peristiwa sebagai variabel yang dipengaruhi (variabel dependen) dan melakukan penyelidikan terhadap variabel yang mempengaruhi (variabel independen). Penelitian ini dilakukan pada desa wisata di Kecamatan Banjar. Populasi dalam penelitian ini adalah seluruh Kepala Desa serta Perangkat Desa di Kecamatan Banjar Kabupaten Buleleng. Metode pengambilan sampel yang digunakan dalam penelitian ini adalah metode purposive sampling, sehingga diperoleh sampel sejumlah 60 responden. Data penelitian ini dikumpulkan dengan menggunakan kuesioner yang kemudian diolah dengan uji analisis regresi linear berganda dengan bantuan SPSS versi 22.

\section{Hasil dan Pembahasan}

Hasil pada penelitian ini meliputi hasil uji statistik deskriptif, uji kualitas data, uji asumsi klasik, dan uji hipotesis. Uji statistik deskriptif dilakukan untuk mengetahui nilai minimum, maksimun, mean dan standar deviasi. Hasil uji statistik deskriptif disajikan pada tabel 1 berikut.

Tabel 1. Hasil Uji Statistik Deskriptif

\begin{tabular}{lccccc}
\hline & $N$ & Min & Max & Mean & Std. Deviation \\
\hline Akuntabilitas Alokasi Dana Desa & 60 & 33 & 48 & 40,42 & 4,681 \\
Kebijakan Desa & 60 & 34 & 46 & 39,45 & 3,629 \\
Kelembagaan Desa & 60 & 35 & 48 & 39,73 & 3,982 \\
Pengelolaan Keuangan Desa Wisata & 60 & 33 & 48 & 39,72 & 4,105 \\
Valid N (listwise) & 60 & & & & \\
\hline
\end{tabular}

Berdasarkan data pada tabel 1 dapat dilihat bahwa variabel akuntabilitas alokasi dana desa $\left(X_{1}\right)$ mempunyai skor minimum 33 , skor maksimum 48 , skor rata-rata 40,42 dengan standar deviasi 4,681. Hal ini menunjukkan bahwa terjadi perbedaan nilai akuntabilitas alokasi dana desa terhadap nilai rata-rata sebesar 4,681. Variabel kebijakan desa $\left(X_{2}\right)$ mempunyai skor minimum 34, skor maksimum 46, skor rata-rata 39,45 dengan standar deviasi 3,629. Hal ini menunjukkan bahwa terjadi perbedaan nilai kebijakan desa terhadap nilai rata-rata sebesar 3.629 .

Variabel kelembagaan desa $\left(X_{3}\right)$ mempunyai skor minimum 35 , skor maksimum 48 , skor rata-rata 39,73 dengan standar deviasi 3,982. Hal ini menunjukkan bahwa terjadi perbedaan nilai kelembagaan desa terhadap nilai rata-rata sebesar 3,982. Variabel pengelolaan keuangan desa wisata $(Y)$ mempunyai skor minimum 33, skor maksimum 48, skor rata-rata 39,72 dengan standar deviasi 4,105. Hal ini menunjukkan bahwa terjadi perbedaan nilai pengelolaan keuangan desa wisata terhadap nilai rata-rata sebesar 4,105.

Uji yang dilakukan selanjutnya adalah uji kualitas data meliputi uji validitas dan uji reliabilitas. Uji validitas bertujuan untuk menguji seberapa baik instrumen penelitian mengukur konsep yang seharusnya diukur. Instrumen dikatakan valid apabila mampu mengukur apa yang seharusnya diukur dan mampu mengungkap data yang diteliti secara tepat. Bila kolerasi tiap variabel positif dan besarnya $>0,30$ menunjukkan bahwa faktor tersebut mempunyai validitas yang kuat (Sugiyono, 2010). Berdasarkan hasil uji validitas dapat dinyatakan bahwa semua instrumen memiliki nilai Pearson Correlation lebih besar daripada 0,3 dan nilai Sig. (2-tailed) korelasi untuk semua item lebih kecil daripada 0,05 sehingga dapat disimpulkan seluruh item pernyataan dinyatakan valid. 
Setelah itu, dilakukan uji reliabilitas secara bersama-sama terhadap seluruh item pertanyaan dalam suatu kuesioner. Hasil pengujian menunjukkan bahwa variabel akuntabilitas alokasi dana desa mempunyai nilai Cronbach's Alpha sebesar 0,905. Variabel kebijakan desa mempunyai nilai Cronbach's Alpha sebesar 0,837. Variabel kelembagaan desa mempunyai nilai Cronbach's Alpha sebesar 0,904. Variabel pengelolaan keuangan desa wisata mempunyai nilai Cronbach's Alpha sebesar 0,891. Semua variabel mempunyai nilai Cronbach's Alpha lebih besar dari 0,60, sehingga dapat dinyatakan bahwa instrumen yang digunakan pada penelitian ini adalah reliabel.

Setelah uji kualitas data terpenuhi, dilakukan uji asumsi klasik. Penelitian ini melakukan 3 uji asumsi klasik yaitu uji normalitas, uji multikolinearitas dan uji heteroskedastisitas. Uji normalitas bertujuan untuk menguji apakah model dalam regresi variable terkait dan variabel bebas keduanya mempunyai distribusi normal atau tidak (Ghozali, 2011). Pengujian normalitas dalam penelitian ini menggunakan uji kolmogorov-sminrov untuk mengetahui data yang digunakan terdistribusi normal atau tidak, kriteria pengujian normalitas menggunakan profitabilitas yang diperoleh dengan level signifikan sebesar 0,05. Dasar pengambilan keputusan adalah (a) jika nilai Sig $\geq 0,05$ maka dikatakan terdistribusi normal dan (b) jika nilai Sig $<0,05$ maka dikatakan distribusi tidak normal. Hasil pengujian yang dilakukan menunjukkan bahwa nilai Kolmogorov Smirnov sebesar 0,166 dengan nilai signifikansi sebesar $0,110>0,05$. Hal ini menunjukkan bahwa nilai residual terdistribusi secara normal dan dapat digunakan dalam penelitian.

Uji asumsi klasik yang kedua yaitu uji multikolinearitas. Uji multikolinearitas bertujuan untuk menguji apakah dalam model regresi ditemukan adanya korelasi yang kuat antar variabel bebas. Apabila nilai Variance Inflation Factor (VIF) tidak lebih dari 10 dan nilai Tolerance tidak kurang dari 0,10 maka model dapat dikatakan terbebas dari multilkoliniaritas dan dapat digunakan dalam penelitian. Hasil pengujian multikolinearitas menunjukkan bahwa semua variabel independen mempunyai nilai VIF lebih kecil daripada 10 dan nilai tolerance lebih besar 0,10, sehingga dapat disimpulkan bahwa model bebas dari multikolinearitas.

Uji asumsi klasik yang selanjutnya dilakukan uji heteroskedastisitas. Uji heteroskedasitas dilakukan untuk menguji apakah dalam sebuah model regresi terjadi ketidaksamaan varians dari residual suatu pengamatan ke pengamatan lain Heteroskedastisitas dapat diketahui melalui uji Glejser. Jika probabilitas signifikan masingmasing variabel independen $>0,05$, maka dapat disimpulkan tidak terjadi heteroskedastisitas dalam model regresi. Hasil uji heteroskedastisitas menunjukkan bahwa masing-masing variabel independen tidak signifikan secara statistik mempengaruhi variabel dependen nilai Absolut Residual (AbsRes). Variabel akuntabilitas alokasi dana desa mempunyai nilai sig. sebesar 0,696, variabel kebijakan desa mempunyai nilai sig. 0,943, dan variabel kelembagaan desa mempunyai nilai sig. sebesar 0,373 . Semua variabel mempunyai probabilitas signifikansi $>0,05$, sehingga disimpulkan model regresi tidak mengandung adanya heteroskedastisitas.

Setelah uji asumsi klasik terpenuhi selanjutnya dilakukan uji hipotesis. Hipotesis pada penelitian ini diuji dengan menggunakan model regresi berganda. Model regresi berganda digunakan untuk memecahkan rumusan masalah yang ada, yaitu untuk melihat pengaruh diantara dua variabel atau lebih. Uji hipotesis yang pertama dilakukan adalah uji koefisien determinasi untuk mengukur seberapa jauh kemampuan model dalam menjelaskan variasi variabel dependen. Apabila Adjusted $\mathrm{R}^{2}$ semakin mendekati 1, maka semakin besar variasi dalam independen variabel, ini berarti semakin tepat garis regresi tersebut untuk mewakili hasil observasi yang sebenarnya. Hasil uji koefisien determinasi pada penelitian ini disajikan dalam tabel 2 berikut.

Tabel 2. Uji Koefisien Determinasi

\begin{tabular}{|l|c|r|r|r|}
\hline Model & $R$ & $R$ Square & Adjusted $R$ Square & Std. Error of the Estimate \\
\hline 1 & $0,886^{\mathrm{a}}$ & 0,784 & 0,773 & 1,95687 \\
\hline
\end{tabular}

Berdasarkan data pada tabel 2 dapat dilihat bahwa nilai Adjusted $R$ Square sebesar 0,773 yang menunjukkan bahwa variasi variabel akuntabilitas alokasi dana desa, kebijakan 
desa, dan kelembagaan desa hanya mampu menjelaskan $77,3 \%$ variasi variabel pengelolaan keuangan desa wisata. Sisanya sebesar $22,7 \%$ dipengaruhi oleh faktor lain di luar penelitian ini yang dapat mempengaruhi pengelolaan keuangan desa wisata.

Hasil uji statistik t pada penelitian ini disajikan pada tabel 3 berikut.

Tabel 3. Hasil Uji Statistik T

\begin{tabular}{|c|c|c|c|c|c|c|}
\hline \multirow{2}{*}{\multicolumn{2}{|c|}{ Model }} & \multicolumn{2}{|c|}{$\begin{array}{c}\text { Unstandardized } \\
\text { Coefficients }\end{array}$} & \multirow{2}{*}{$\begin{array}{c}\begin{array}{c}\text { Standardized } \\
\text { Coefficients }\end{array} \\
\text { Beta }\end{array}$} & \multirow[b]{2}{*}{$T$} & \multirow[b]{2}{*}{ Sig. } \\
\hline & & $B$ & Std. Error & & & \\
\hline \multirow[t]{4}{*}{1} & (Constant) & 4,412 & 2,849 & & 1,549 & 0,127 \\
\hline & Akuntabilitas Alokasi Dana Desa & 0,092 & 0,100 & 0,105 & 2,922 & 0,036 \\
\hline & Kebijakan Desa & 0,086 & 0,112 & 0,076 & 2,767 & 0,045 \\
\hline & Kelembagaan Desa & 0,880 & 0,136 & 0,854 & 6,495 & 0,000 \\
\hline
\end{tabular}

a. Dependent Variable: Pengelolaan Keuangan Desa Wisata

Berdasarkan data pada tabel 3 dapat dilihat bahwa variabel akuntabilitas alokasi dana desa $\left(X_{1}\right)$ mempunyai $t_{\text {hitung }}$ sebesar 2,922 $>t_{\text {tabel }}$ sebesar 2,003 dengan nilai signifikansi sebesar $0,036<0,05$. Nilai T positif menunjukkan bahwa variabel $X_{1}$ mempunyai hubungan yang searah dengan $\mathrm{Y}$. Jadi dapat disimpulkan bahwa $\mathbf{H}_{\mathbf{1}}$ diterima yaitu akuntabilitas alokasi dana desa berpengaruh positif dan signifikan terhadap pengelolaan keuangan desa wisata.

Variabel kebijakan desa mempunyai thitung sebesar 2,767 $>t_{\text {tabel }}$ sebesar 2,003 dengan nilai signifikansi sebesar 0,045 $<0,05$. Nilai $T$ positif menunjukkan bahwa variabel $X_{2}$ mempunyai hubungan yang searah dengan $\mathrm{Y}$. Jadi dapat disimpulkan bahwa $\mathbf{H}_{2}$ diterima yaitu kebijakan desa berpengaruh positif dan signifikan terhadap pengelolaan keuangan desa wisata.

Variabel kelembagaan desa mempunyai $t_{\text {hitung }}$ sebesar 6,495 $>t_{\text {tabel }}$ sebesar 2,003 dengan nilai signifikansi sebesar $0,000<0,05$. Nilai T positif menunjukkan bahwa variabel $X_{3}$ mempunyai hubungan yang searah dengan $\mathrm{Y}$. Jadi dapat disimpulkan bahwa $\mathbf{H}_{3}$ diterima yaitu kelembagaan desa berpengaruh positif dan signifikan terhadap pengelolaan keuangan desa wisata.

Selanjutnya dilakukan uji statistik F. Uji F atau uji serentak dapat disebut uji statistik secara simultan, yaitu uji statistik bagi koefisien regresi yang serentak atau bersama-sama mempengaruhi $Y$. Uji serentak atau uji $F$ ini menggunakan tingkat signifikan 0,05, jika nilai signifikansi lebih kecil daripada 0,05 maka terdapat pengaruh secara bersama-sama antara variabel bebas dengan variabel terikatnya. Hasil uji statistik $\mathrm{F}$ disajikan pada tabel 4 berikut.

Tabel 4. Hasil Uji Statistik F

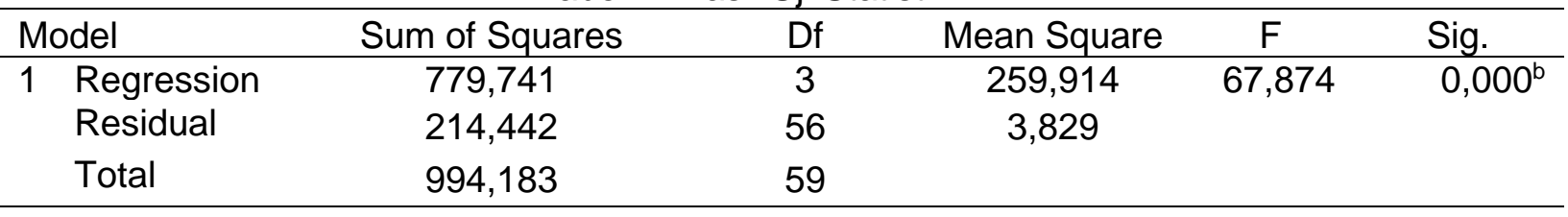

Berdasarkan data pada tabel 4 dapat dilihat bahwa nilai signifikansi sebesar $0,000<$ 0,005 . Hal ini menunjukkan bahwa variabel independen secara bersama-sama berpengaruh signifikan terhadap variabel dependen. Jadi dapat disimpulkan bahwa $\mathbf{H}_{\mathbf{4}}$ diterima yaitu akuntabilitas alokasi dana desa, kebijakan desa, dan kelembagaan desa secara bersamasama berpengaruh signifikan terhadap pengelolaan keuangan desa wisata.

Dalam tabel dapat dilihat bahwa variabel akuntabilitas alokasi dana desa $\left(X_{1}\right)$ mempunyai thitung sebesar 2,922 $>t_{\text {tabel }}$ sebesar 2,003 dengan nilai signifikansi sebesar 0,036 $<0,05$. Nilai t positif menunjukkan bahwa variabel $X_{1}$ mempunyai hubungan yang searah dengan $\mathbf{Y}$. Jadi dapat disimpulkan bahwa $\mathbf{H}_{\mathbf{1}}$ diterima yaitu akuntabilitas alokasi dana desa berpengaruh positifdan signifikan terhadap pengelolaan keuangan desa wisata. 
Secara teori, akuntabilitas adalah kemampuan memberi jawaban kepada otoritas yang lebih tinggi atas tindakan seseorang/sekelompok orang terhadap masyarakat luas dalam suatu organisasi (Rasul, 2002 dalam Justita 2016).Tuntunan akuntabilitas sektor publik terkait dengan perlunya dilakukan transparansi dan pemberian informasi kepada publik dalam rangka pemenuhan hak-hak publik. Akuntabilitas publik adalah kewajiban pihak pemegang amanah untuk memberikan pertanggungjawaban, menyajikan, melaporkan dan mengungkapkan segala aktivitas dan kegiatan yang menjadi tanggungjawabnya kepada pihak yang memberikan amanah. Akuntabilitas publik terdiri atas dua macam, yaitu: akuntabilitas vertikal (vertical accountability), dan akuntabilitas horizontal (horizontal accountability).

Pemerintah daerah mengharapkan kebijakan Alokasi Dana Desa ini dapat mendukung pelaksanaan pembangunan partisipatif berbasis masyarakat dalam upaya pemberdayaan masyarakat pedesaan sekaligus memelihara kesinambungan pembangunan di tingkat desa. Dengan adanya Alokasi Dana Desa, desa memiliki kepastian pendanaan sehingga pembangunan dapat terus dilaksanakan tanpa harus terlalu lama menunggunya dana bantuan dari pemerintah pusat. Dalam hal ini desa harus merancang perencanaan keuangan secara matang dalam pengelolaan alokasi dana desa dan melakukan kegiatan dengan penatausahaan yang baik. Hasil kegiatan yang dilakukan tersebut dilaporkan sebagai bentuk pertanggungjawaban desa dalam mengelola keuangannya.

Penelitian ini dikaji dengan menggunakan stewardship theory yang menggambarkan situasi dimana para manajemen organisasi tidaklah termotivasi oleh tujuan-tujuan individu tetapi lebih ditunjukan pada sasaran hasil utama mereka untuk kepentingan organisasi.Dalam konsep stewardship theorydijelaskan bahwa manajer atau pejabat desa akan berperilaku sesuai kepentingan bersama (Raharjo, 2007 dalam Justita, 2016).

Akuntabilitas berhubungan dengan stewardship theory karena akuntabilitas berkaitan dengan pertanggungjawaban pimpinan atas keputusan dan hasil yang dicapai, sama halnya dengan stewardship theory yaitu dapat dipercaya, memiliki integritas, bertanggungjawab atas setiap tindakannya. Dalam hal ini alokasi dana desa yang diberikan kepada desa tentu digunakan untuk kepentingan bersama melalui perencanaan yang matang dalam penyusunan laporan pertanggungjawaban terkait dana desa yang dikelola tersebut.

Berdasarkan konsep yang ada dan pengujian yang telah dilakukan tampak bahwa akuntabilitas alokasi dana desa memiliki pengaruh terhadap pengelolaan keuangan desa wisata. Hasil penelitian menunjukkan bahwa akuntabilitas alokasi dana desa memiliki hubungan searah dengan pengelolaan keuangan desa wisata. Hal ini berarti bahwa semakin tinggi tingkat akuntabilitas alokasi dana desa maka pengelolaan keuangan desa wisata akan semakin baik pula. Penelitian yang berkaitan dengan pengelolaan keuangan desa juga pernah dilakukan oleh (Justita, 2016) yang meneliti tentang kesejahteraan masyarakat desa dengan hasil penelitian yang menunjukkan bahwa akuntabilitas alokasi dana desa berpengaruh secara signifikan terhadap kesejahteraan masyarakat di desa Gubugklakah Poncokusumo Kabupaten Malang.

Berdasarkan hasil uji statistik $\mathrm{T}$ dapat dilihat bahwa variabel kebijakan desa mempunyai thitung sebesar 2,767 > t tabel sebesar 2,003 dengan nilai signifikansi sebesar 0,045 $<0,05$. Nilai $t$ positif menunjukkan bahwa variabel $X_{2}$ mempunyai hubungan yang searah dengan $\mathrm{Y}$. Jadi dapat disimpulkan bahwa $\mathbf{H}_{2}$ diterima yaitu kebijakan desa berpengaruh positif dan signifikan terhadap pengelolaan keuangan desa wisata.

Secara teori, kebijakan adalah pedoman-pedoman dan ketentuan-ketentuan yang dianut atau dipilih dalam melaksanakan (memanage) suatu program untuk mencapai tujuan tertentu. Perencanaan adalah semua kegiatan (planning) yang dilakukan sebelum melakukan suatu kegiatan, dari suatu program proyek, yakni menentukan tujuan objective, tujuan antara, kebijakan, prosedur dan program.

Kebijakan pemerintah desa merupakan salah satu produk hukum karena setiap pemerintah desa secara hukumpun memiliki wewenang tersebut. Meskipun berskala kecil dan lokal yang mencangkup wilayah administrasi desa itu sendiri. Meskipun demikian desa memiliki hak dan wewenang berpartisipasi dalam menentukan arah pembangunan nasional secara umum serta pembangunan desa sendiri secara khusus (Justita, 2016).Dalam hal ini, 
dalam pelaksanaan operasional desa tentu harus adanya komunikasi yang memadai, sumber daya yang berkompeten dengan struktur birokrasi yang baik, sehingga mampu menunjang keberhasilan pengelolaan keuangan desa.

Akuntansi organisasi sektor publik pada awal perkembangannya disiapkan guna memberikan informasi dari hubungan Stewards (pemerintah) dengan principals (masyarakat). Dikarenakan tuntuntan akan akuntabilitas terus bertambah, principals semakin sulit untuk menjalankan fungsi-fungsi pengelolaan sendiri. Karena keterbatasan tersebut principals (masyarakat) mempercayakan pengelolaan sumber daya yang mereka miliki kepada pihak yang dirasa lebih capable yaitu stewards (pemerintah). Dalam hal ini tentu kebijakan-kebijakan yang dikeluarkan desa harus mencerminkan kenyataan di lapangan dan terjalinnya komunikasi yang baik dalam memanage sumber daya untuk kepentingan bersama sesuai dengan konsep teori stewardship.

Berdasarkan konsep yang ada dan pengujian yang telah dilakukan tampak bahwa kebijakan desa dapat mempengaruhi pengelolaan keuangan desa wisata. Hasil penelitian menunjukkan bahwa kebijakan desa memiliki hubungan searah dengan pengelolaan keuangan desa wisata. Hal ini berarti bahwa semakin baik kebijakan desa maka pengelolaan keuangan desa akan semakin baik pula. Hasil penelitian ini sejalan dengan penelitian yang dilakukan oleh (Justita, 2016) yang meneliti tentang kesejahteraan masyarakat dengan hasil penelitian yang menunjukkan bahwa kebijakan desa berpengaruh signifikan terhadap kesejahteraan masyarakat di desa Gubugklakah Kecamatan Poncokusumo Kabupaten Malang.

Pada hasil penujian ditemukan bahwa variabel kelembagaan desa mempunyai $t_{\text {hitung }}$ sebesar 6,495 $>t_{\text {tabel }}$ sebesar 2,003 dengan nilai signifikansi sebesar $0,000<0,05$. Nilai $t$ positif menunjukkan bahwa variabel $\mathrm{X}_{3}$ mempunyai hubungan yang searah dengan $\mathrm{Y}$. Jadi dapat disimpulkan bahwa $\mathbf{H}_{3}$ diterima yaitu kelembagaan desaberpengaruh positifdan signifikan terhadap pengelolaan keuangan desa wisata.

Secara teori, lembaga atau institusi adalah wadah untuk mengemban tugas dan fungsi tertentu dalam rangka mencapai tujuan tertentu.Oleh karena itu keberadaan lembaga desa merupakan wadah untuk mengemban tugas dan fungsi Pemerintahan Desa. Tujuan penyelenggaraan pemerintah Desa adalah untuk meningkatkan kesejahteraan masayarakat, sehingga tugas pemerintah desa adalah memberikan pelayanan (service) dan pemberdayaan (empowerment), serta pembangunan (development) yang seluruhnya ditujukan bagi kepentingan nasyarakat.Istilah lembaga identik dengan organisasi.Dalam suatu organisasi senantiasa terdapat struktur organisasi yang jelas.

Stewardshiptheory menggambarkan bahwa manajemen dapat berperilaku baik demi kepentingan banyak pihak, sehingga tercipta hubungan yang kuat antara kepuasan organisasi dan kesuksessannya. Kesuksesan organisasi dapat dicapai dengan cara memaksimalkan utilitas manajemen dan principal. Dalam mempertangungjawabkan keuangan yang telah diberikan oleh pemerintah, lembaga desa tersebut harus memberikan pelayanan yang baik, dipercaya oleh masyarakat atas pengelolaan keuangan desa, harus transparan mengenai danayang diberikan oleh pemerintah untuk desa ke masyarakat agar masyarakat itu sendiri percaya atas apa yang dilakukan desa untuk membangun desa yang lebih bersih, jujur, dan transparan.

Berdasarkan konsep yang ada dan pengujian yang dilakukan tampak bahwa kelembagaan desa dapat mempengaruhi pengelolaan keuangan desa wisata. Hasil penelitian menunjukkan bahwa kelembagaan desa memiliki hubungan searah dengan pengelolaan keuangan desa wisata. Hasil penelitian ini sejalan dengan penelitian yang dilakukan oleh (Justita, 2016) yang meneliti tentang kesejahteraan masyarakat dengan hasil penelitian yang menunjukkan bahwa kelembagaan desa berpengaruh signifikan terhadap kesejahteraan masyarakat di desa Gubugklakah Kecamatan Poncokusumo Kabupaten Malang.

Pengujian seluruh variabel secara simultan menunjukkan bahwa bahwa nilai signifikansi sebesar 0,000 $<0,005$. Hal ini menunjukkan bahwa variabel independen secara bersama-sama berpengaruh signifikan terhadap variabel dependel. Jadi dapat disimpulkan bahwa $\mathbf{H}_{4}$ diterima yaitu akuntabilitas alokasi dana desa, kebijakan desa, dan kelembagaan 
desa secara bersama-sama berpengaruh signifikan terhadap pengelolaan keuangan desa wisata.

Secara teori, pengelolaan keuangan desa adalah keseluruhan kegiatan yang meliputi perencanaan, pelaksanaan, penatausahaan, pelaporan, dan pertanggungjawaban keuangan desa.Penyelenggaraan kewenangan Desa berdasarkan hak asal usul dan kewenangan lokal berskala Desa didanai oleh APBDesa. Penyelenggaraan kewenangan lokal berskala Desa selain didanai oleh APBDesa, juga dapat didanai oleh anggaran pendapatan dan belanja negara dan anggaran pendapatan dan belanja daerah. Penyelenggaraan kewenangan Desa yang ditugaskan oleh Pemerintah didanai oleh anggaran pendapatan dan belanja negara.

Penelitian ini dikaji dengan stewardship theory yang menggambarkan bahwa manajemen dapat berperilaku baik demi kepentingan banyak pihak, sehingga tercipta hubungan yang kuat antara kepuasan organisasi dan kesuksessannya. Stewardship theory dalam penelitian akuntabilitas alokasi dana desa, kebijakan desa dan kelembagaan desa atas pengelolaan keuangan desa wisata yaitu alokasi dana yang diberikan oleh pemerintah untuk desa digunakan untuk pengembangan desa atau digunakan untuk mengembangkan wisata desa tersebut dapat di pertanggungjawabkan oleh desa agar desa sebagai organisasi sektor publik dapat di percaya untuk mensejahterakan masyarakat desa itu sendiri.

Berdasarkan konsep yang ada dan pengujian yang dilakukan tampak bahwa akuntabilitas alokasi dana desa, kebijakan desa, dan kelembagaan desa dapat mempengaruhi pengelolaan keuangan desa. Sesuai hasil uji statistik $F$ yang menunjukkan nilai signifikansi $0,000<0,05$ yang berarti bahwa variabel independen (akuntabilitas alokasi dana desa, kebijakan desa, kelembagaan desa) secara bersama-sama berpengaruh signifikan terhadap variabel dependen (pengelolaan keuangan desa wisata).

\section{Simpulan dan Saran}

Peneliti menyimpulkan bahwa akuntabilitas alokasi dana desa, kebijakan desa, dan kelembagaan desa berpengaruh positif terhadap pengelolaan keuangan desa pada desadesa di Kecamatan Banjar. Artinya bahwa apabila dilandaskan pada stewardship theory maka pengelolaan keuangan desa perlu didasari oleh pengelolaan yang bertangungjawab, berintegritas dan dipercaya, dengan memaksimalkan manajerial desa sehingga pengelolaan keuangan desa sesuai kebutuhan nyata desa.

Peneliti menyarankan agar desa-desa di Kecamatan Banjar, yang belum melakukan pembenahan untuk wisata yang dimiliki, dikarenakan pengelolaan keuangan yang kurang baik maka perlu untuk merancang kebijakan-kebijakan yang baik melalui komunikasi dan disposisi yang terstruktur serta meningkatkan kompetensi sumber daya manusia yang akan melaksanakan kebijakan-kebijakan desa tersebut, sehingga kebijakan desa akan terlaksana dengan baik dan dapat menjadi desa wisata yang lebih maju. Bagi peneliti selanjutnya disarankan dapat menambah jumlah sampel dan mempertimbangkan variabel lain yang belum diuji dalam penelitian ini yang mempunyai pengaruh terhadap pengelolaan keuangan desa wisata, seperti kompetensi sumber daya manusia, tingkat kompensasi, tingkat pendidikan dan lain sebagainya.

\section{Daftar Rujukan}

Azwardi, Sukanto, 2014. Efektifitas Alokasi Dana Desa (ADD) dan Kemiskinan di Provinsi Sumatera Selatan. Jurnal Ekonomi Pembangunan, Vol. 12, No. 1, Hal: 29-41.

Erni, Tahir. 2018. Pengaruh Alokasi Dana Desa Terhadap Pemberdayaan Dan Peningkatan Kesejahteraan Masyarakat (Studi pada Desa Jaya Makmur Kecamatan Binongko Kabupaten Wakatobi). Skripsi. Universitas Halu Oleo Kendari.

Ghozali. Imam. 2011. Aplikasi Analisis Multivariate dengan Program SPSS. Semarang: Badan Penerbit Universitas Diponegoro.

Justita. 2016. Pengaruh Akuntabilitas Pengelolaan Keuangan Alokasi Dana Desa, Kebijakan Desa, Dan Kelembagaan Desa Terhadap Kesejahteraan Masyarakat (Studi Kasus 
Pada Desa Gubugklakah Kecamatan Poncokusumo Kabupaten Malang). Jurnal IImiah Bisnis dan Ekonomi STIE Asia, Vol. 10, No. 1.

Maulana, 2017. Pengelolaan Alokasi Dana Desa Dalam Meningkatkan Pemberdayaan Masyarakat di Desa Miau Baru Kecamatan Kongbeng Kabupaten Kutai Timur. EJournal Administrasi Negara, Vol. 5, No. 1, Hal: 5188-5200.

Ompi, Atika Wulan. 2012. Implementasi Kebijakan Alokasi Dana Desa (ADD) Dalam Meningkatkan Pembangunan Desa (Studi di Desa Pangu Kec. Ratahan Kab. Minahasa Tenggara). Jurnal IImiah, Vol. 5, No. 1.

Subroto, Agus. 2009. Akuntabilitas Pengelolaan Dana Desa (Studi Kasus Pengelolaan Alokasi Dana Desa Di Desa-Desa Dalam Wilayah Kecamatan Tlogomulyo Kabupaten Temanggung Tahun 2008. Tesis. Universitas Diponegoro.

Thomas, 2013, Pengelolaan Alokasi Dana Desa Dalam Upaya Meningkatkan Pembangunan $\mathrm{Di}$ Desa Sebawang Kecamatan Sesayap Kabupaten Tana Tidung. Jurnal Pemerintahan Integratif, Vol. 1, No. 1, Hal: 51-64.

Winata, S.P. 2018. Peran Lembaga Pemberdayaan Masyarakat Kelurahan dalam Memberdayakan Masyarakat di Kelurahan Sungai Pagar Kecamatan Kampar Kiri Kabupaten Kampar Tahun 2016. JOM FISIP.Vol. 5, No. 1.

Yoyok, Sudarmaji. 2009. Pengelolaan Keuangan Desa (Studi Kasus Pengelolaan Keuangan Desa Bakaran Kulon Kecamatan Juwana Kabupaten Pati). Tesis. Universitas Diponegoro. 